\title{
An Exploration in the Fields of Home Science and home Economics and their Impact on School Education in Context of Asian Countries
}

\author{
Neeta Panchmukh \\ MIT School of Education \& \\ Research, \\ MIT Art, Design \& Technological \\ University Pune, India
}

\author{
Remica Aggarwal \\ MIT School of Education \& \\ Research, \\ MIT Art, Design \& Technological \\ University Pune, India
}

\author{
Veena Aggarwal \\ Recventures Education Services \\ Private Limited, \\ Delhi, India
}

\begin{abstract}
The study of Home Science helps each people lead a more satisfying personal, family and community life because of the knowledge, understanding, skills and appreciation of cultural and spiritual values a pupil gained through the course. Home economics on the other hand counts as an interdisciplinary degree that focuses on the economics of running a household. It is an inter-disciplinary subject which includes classes in chemistry, food preparation, fine arts, accounting and basiceconomics. Present research work explores the two interesting disciplines and further explore how they could impact in upgrading or enhancing school education. Further it studies the interrelationships amongst various barriers to successful teaching of home science and home economics in Indian secondary school setup using ISM model .
\end{abstract}

\section{Keywords}

Partnering, ISM methodology, Construction project management

\section{INTRODUCTION}

\subsection{Pedagogies in science and economics}

Science teachers have a dual responsibility to nurture future scientists and to develop broad scientific literacy in students. This makes them use scientific knowledge, to identify questions and to draw evidence-based conclusions in order to understand and help make decisions about the natural world and the changes made to it through human activity. The distinct objectives of science education at secondary school includes arranging pre-professional education around mathematics, physics, chemistry, biology and perhaps general science. The second is the citizen focused need for all children as they mature to have a clear understanding of the complex world of science that they will confront as citizens over the next 60 years of their lives [1]. For students to understand that science programmes can be interesting and relevant to them, teachers may need to break down stereotypes about science, those who take science, and those who should consider science-related careers. Teachers also need to review all aspects of teaching and learning, from programme design and choice of contexts through to the safety and inclusivity of learning environments and the nature of teacher-student interactions.

Economics is a dynamic subject which touches our lives daily. Ranging from taking decisions on whether to buy a pair of shoes to whether to take a loan to purchase a house, all such decisions are driven by economic principles. The traditional school setting is based on axioms that are outdated and mismatched to current research undertaken in the field of education that supports and provides evidences how a child improves learning. It is therefore required in the present scenario to change the focus of the classroom from the teacher to the learner to make the subject of economics more interesting. However, few strategies such as interactive lectures through brainstorming, asking for examples and sharing of students' personal experiences relevant to a topic could be encouraging for students. Strategies beyond lectures included small group collaborative learning methods that range from using the print and electronic media to undertake group discussions, problem solving based learning, case studies, project work and games. In fact, peer teaching engages students and helps children learn in a non- threatening environment.

\subsection{Home science and home economics}

Home science also known as domestic science was introduced during the British rule between 1920s - 1940 as a disciplinary subject in the princely state of Baroda. Thereafter, a diploma course was started by agricultural institute of Allahabad in 1935. Since 1950 outstanding Home Science Colleges were started at Coimbatore (Tamil Nadu), Ludhiana (Punjab), Bombay (Maharashtra), New Delhi, Udaipur (Rajasthan) and Tirupathi (Andhra Pradesh). In the mid 1960's and 1970's, agricultural universities were established in most of the states. The modern concept of home science focuses on bringing peace, prosperity and progress in family and homes and also to awaken the women's issues. Along with material and economic achievements, physical, spiritual and moral aspects of family living have to be promoted. The home implants moral values of honesty, truthfulness, dependability and objectivity in a person. The study of Home Science helps each people lead a more satisfying personal, family and community life because of the knowledge, understanding, skills and appreciation of cultural and spiritual values a pupil acquire through this discipline . Unlike other subjects, home science is a practical science one applies in everyday life. As a practical subject it offers maximum opportunity to express one's ability to take up things and develop leadership roles.

Major areas in home science includes food \& nutrition , textile science, family and community resource management, extension education and human development . The following benefits are recognized: 
1. Home science education helps pupil to recognize the importance of food in healthy living, teaches how to prepare food by retaining its nutrients and the importance of balanced diet.

2. Home Science education helps one to start selfemployment and become a wage earner at younger age.

3. 3.The curriculum empowers to take intelligent decisions concerning the use of materials and resources.

4. Physical, motor, emotional, language, cognitive and social developments of human beings are included in this.

5. Behavioral problems of children, exceptional children, disorders, specific problems and issues that hinder the development of human beings are also dealt with.

6. Geriatrics is also a part of the study since the life span of an individual is longer today.

7. Under Family and Community Resource Management, time, money, energy and space management are the main topics for study.

8. A good time plan is essential for time management. For money management resources have to be utilized judiciously.

9. Consumer education which includes information related to food safety, safety against adulteration, common adulterants, health hazards and consumer protection act.

10. Major principles and basics of design and arts are also detailed in this area.

Home economics on the other hand is an inter-disciplinary subject which includes classes in chemistry, food preparation, fine arts, accounting and basic economics. One of the primary lessons that a student learns during the course of a home economics education is how to prepare food, about its nutritional value and proper portion sizes. He/ She also learns about how to budget when shopping for food, bringing an additional economics lesson to her studies. Home economics is more popular abroad. Home economics classes acted as a bridge during the 20th Century for women to enter into institutions of higher education and later into professions. When first introduced in the late $1800 \mathrm{~s}$, these classes helped girls prepare for life on the farm helping their families. As universities conducted research, home economics classes taught advanced classes in nutrition and hygiene as well as economics. Women who graduated from these advanced programs went on to teaching positions to pass on this knowledge.

The paper is organized as follows. Section 2 describes home science as a vocation and its various application areas . Thereafter managerial implications and future directions have been described in section 3 .

\section{MAJOR CUSTOMERS OF HOME SCIENCE AND HOME ECONOMICS}

\subsection{Hospitality and Tourism}

- It can be seen that people utilize their education in home economics not only to manage their home or business but also industries such as hospitality and tourism are the prime candidates for this type of education

- Hospitality and tourism makes use of the applications of the subjects of in food science and nutrition, fine arts and decoration, as well as business and accounting. When looked at in this context, because these skills can be used to decorate a hotel lobby or to choose the look of the interior of a restaurant.

\subsection{Environmental Sustainability}

According to a report by Education for Sustainable Development, the United Nations has declared the years between 2005 and 2014 a time of advancing knowledge about sustainability, as well as taking action to that end. Home economics education has a large part to play in this. Aside from teaching their students about the energy required to grow, package and store food and other items, students in programs such as these learn how to reuse items in new ways. This can include reusing clothing and other household items in different ways than they were originally intended or using recyclable materials when making clothing and other items.

\subsection{Family Finance}

Whether a woman is a homemaker, career-driven, married or single, handling personal finances is a skill that everyone needs to know, and yet is no longer taught in most schools. In 2010, Americans owed over 2,400 billion dollars in consumer debt. The news is filled with stories of foreclosures on homes; and homeownership, that icon of the American Dream, is declining. Though the recent recession has certainly hit many families hard, it is also clear that most people do not understand the basics of managing personal finances. Home economics classes taught students how to open bank accounts and how to balance a checking account.

\subsection{Nutrition and Cooking}

While cooking is perhaps the skill people most associate with home economics, like personal finance, it is a practical skill that most people will need during life. Health experts are alarmed at the rise in obesity in the nation, which is thought to be caused by a combination of factors, like a more sedentary lifestyle, prevalence of fast food, and the high use of overly processed foods in the home. In a society when both men and women are preparing for careers, basic skills like cooking are often neglected. However, a home economics class can prepare anyone to prepare healthy and nutritious meals for themselves and their family no matter their schedule. Home science as well as home economics classes can teach the latest research in nutrition and food safety. This is a constantly changing topic as scientists learn and understand more about how the human body works. A home economics teacher can then take this knowledge and help the students apply it in their lives. 


\subsection{Textiles}

While modern home economics classes still teach sewing, the repertoire has expanded. Along with basic sewing skills, pupils can also learn how to make curtains and other items for the home. They are also taught about different textiles: their qualities, care, and purposes. This includes how to do laundry properly to extend the life of clothing. Advanced classes even delve into both fashion and interior design. While most people don't sew their own clothing anymore, everyone must wear clothes. These classes help students understand what colors complement them, and how to dress their body style. Learning how to recognize quality clothing is also a key skill.

\section{BARRIERS TO SUCCESSFUL IMPLEMENTATION OF HOME SCIENCE AND HOME ECONOMICS IN SECONDARY SCHOOLS [2-10]}

3.1. Teacher's competence (TC) : It has been found in the previous researches that home science teachers rely largely on the knowledge acquired during initial professional training and on their classroom experience. A teachers' competence may be impacted upon by changes in policy and subsequently on the syllabus because it reflects on the ability to teach new skills or use new techniques.

3.2. Teaching load(TL) : This factor can also be considered against the number of students taught. Another factor that determines the class size was the perceptions of the students.

3.3 Inappropriate class size (ICS) : The variance in the class sizes from year to year has the implications for effective resource use. Assuming that schools have fully equipped home science facilities, in some years, the resources would be over stretched, in others under-utilized. Class size in relation to the facilities, material and equipment available for home science is an important aspect of policy implementation. Fewer class size could serve as barrier.

3.4. Lack of appropriate facilities for home science and home economics (LAF): Each learner in a home science needs equipment and materials to practice concepts taught. If the teacher does not have the well-equipped laboratories and access to the materials needed to carry out practical classes she may resort to theoretical coverage of the syllabus .

3.5. Less number of practical lessons (LPL) : As a prevocational subject practice of the principles learnt in the class is central to attaining the required competencies in home science. The secondary home science teachers' guide suggest practical activities for most lessons, and give guidance to the teacher about the resources that can be used to achieve this. However in the absence of resources available and time, most of the teachers finds it difficult to follow the syllabus closely in this regard.

3.6 Too much content to be covered in a semester (TMC): The field of home science and home economics is so vast that it becomes very difficult to cover the entire contents in the stipulated time.

3.7 Less popular amongst males (LPM) : Home science education is quite of less interest amongst male students .

3.8 Lack of up-dation and improvisation in the age long pedagogy (LUI) : There is a requirement to improvise the present course content to meet the changing need of society .
3.9 Requirement of skilled and experienced teacher (LEST) who can take up the subject as per the pedagogical requirements.

\section{INTERPRETIVE STRUCTURAL MODELLING METHODOLOGY}

Interpretive structural modelling methodology or ISM [11] is a known technique to map the relationships amongst the relevant elements as per decision maker's problems in a hierarchical manner. Starting with the identification of elements, it proceeds with establishing the contextual relationships between elements (by examining them in pairs ) and move on towards developing the structural selfinteraction (SSIM) matrix using VAXO [11] and then initial reachability matrix and final reachability matrix and rearranging the elements in topological order using the level partition matrices. A Mic-Mac analysis is performed afterwards which categorize the variables as per the driving and dependence power in to autonomous, dependent, driver and linkage category. Finally, a diagraph can be obtained.

\section{DEVELOPMENT OF ISM MODEL}

In this section, ISM model is developed for studying the interrelationships amongst various barriers to successful teaching of home science and home economics in Indian secondary school setup. Some eight barriers have been recognised viz. Teacher's competence (TC) ; Teaching load(TL); Inappropriate class size (ICS) ; Lack of appropriate facilities for home science and home economics (LAF) ; Less number of practical lessons (LPL); Too much content to be covered in a semester (TMC) ; Less popular amongst males (LPM) ; Lack of up-dation and improvisation in the age long pedagogy (LUI) ; Requirement of skilled and experienced teacher (LEST)

\subsection{Construction of Structural Self - Interaction Matrix (SSIM)}

This matrix gives the pair-wise relationship between two variables i.e. $\mathrm{i}$ and $\mathrm{j}$ based on VAXO. SSIM has been presented below in Fig 1.

Explanation: Teaching load affects teacher's competence and vice versa. Less competent teacher may have inappropriate or small class size. Lack of appropriate facilities affects teacher's competence. More teaching load may lead to less practical lessons. Too much content may also lead to less practical lessons . Too much content affects teachers' competence as well as teaching load and vice versa. less number of class size affects the content to be covered. Sometimes it could motivate the teacher as they have to handle less number of student. Sometimes it could be a demotivating factor. A teacher with too much teaching load may not take the practical sessions with that interest.

\subsection{Construction of Initial Reachability Matrix and final reachability matrix}

The SSIM has been converted in to a binary matrix called the initial reachability matrix shown in fig. 2 by substituting $\mathrm{V}, \mathrm{A}$, $\mathrm{X}, \mathrm{O}$ by 1 or 0 as per the case. After incorporating the transitivity, the final reachability matrix is shown below in the Fig 3. 
Fig 1: SSIM matrix for pair wise relationship amongst barriers

\begin{tabular}{|l|l|l|l|l|l|l|l|l|l|l|}
\hline S.No. & Barriers & 1 & 2 & 3 & 4 & 5 & 6 & 7 & 8 & 9 \\
\hline & & TC & TL & ICS & LAF & LPL & TMC & LPM & LUI & LEST \\
\hline 1 & TC & & X & V & A & V & X & O & A & A \\
\hline 2 & TL & & & A & A & V & X & O & A & A \\
\hline 3 & ICS & & & & X & V & V & A & A & A \\
\hline 4 & LAF & & & & & V & V & V & A & A \\
\hline 5 & LPL & & & & & & A & V & A & A \\
\hline 6 & TMC & & & & & & & V & A & A \\
\hline 7 & LPM & & & & & & & & A & A \\
\hline 8 & LUI & & & & & & & & & A \\
\hline 9 & LEST & & & & & & & & & \\
\hline
\end{tabular}

Fig 2: Initial reachability matrix

\begin{tabular}{|l|l|l|l|l|l|l|l|l|l|l|}
\hline S.No. & Barriers & 1 & 2 & 3 & 4 & 5 & 6 & 7 & 8 & 9 \\
\hline & & TC & TL & ICS & LAF & LPL & TMC & LPM & LUI & LEST \\
\hline 1 & TC & 1 & 1 & 1 & 0 & 1 & 1 & 0 & 0 & 0 \\
\hline 2 & TL & 1 & 1 & 0 & 0 & 1 & 1 & 0 & 0 & 0 \\
\hline 3 & ICS & 0 & 1 & 1 & 1 & 1 & 1 & 0 & 0 & 0 \\
\hline 4 & LAF & 1 & 1 & 1 & 1 & 1 & 1 & 1 & 0 & 0 \\
\hline 5 & LPL & 0 & 0 & 0 & 0 & 1 & 0 & 1 & 0 & 0 \\
\hline 6 & TMC & 1 & 1 & 0 & 0 & 1 & 1 & 1 & 0 & 0 \\
\hline 7 & LPM & 0 & 0 & 1 & 0 & 0 & 0 & 1 & 0 & 0 \\
\hline 8 & LUI & 1 & 1 & 1 & 1 & 1 & 1 & 0 & 1 & 0 \\
\hline 9 & LEST & & & & & & & & & 1 \\
\hline
\end{tabular}

Fig 3 : Final reachability matrix

\begin{tabular}{|l|l|l|l|l|l|l|l|l|l|l|l|}
\hline S.No. & Barriers & 1 & 2 & 3 & 4 & 5 & 6 & 7 & 8 & 9 & \\
\hline & & TC & TL & ICS & LAF & LPL & TMC & LPM & LUI & LEST & D.P \\
\hline 1 & TC & 1 & 1 & 1 & 1 & 1 & 1 & 1 & 0 & 0 & 7 \\
\hline 2 & TL & 1 & 1 & 1 & 0 & 1 & 1 & 1 & 0 & 0 & 6 \\
\hline 3 & ICS & 1 & 1 & 1 & 1 & 1 & 1 & 1 & 0 & 0 & 7 \\
\hline 4 & LAF & 1 & 1 & 1 & 1 & 1 & 1 & 1 & 0 & 0 & 7 \\
\hline 5 & LPL & 0 & 0 & 1 & 0 & 1 & 0 & 1 & 0 & 0 & 3 \\
\hline 6 & TMC & 1 & 1 & 1 & 0 & 1 & 1 & 1 & 0 & 0 & 5 \\
\hline 7 & LPM & 0 & 1 & 1 & 1 & 1 & 1 & 1 & 0 & 0 & 6 \\
\hline 8 & LUI & 1 & 1 & 1 & 1 & 1 & 1 & 1 & 1 & 0 & 8 \\
\hline 9 & LEST & 1 & 1 & 1 & 1 & 1 & 1 & 1 & 1 & 1 & 9 \\
\hline & De.P. & 6 & 7 & 8 & 5 & 8 & 7 & 8 & 1 & 1 & \\
\hline
\end{tabular}

D.P : Driving power ; De.P : dependence power 


\subsection{Level Partition}

Table 1 : Iteration I

\begin{tabular}{|c|c|c|c|c|}
\hline S.No. & $\begin{array}{c}\text { Reachability } \\
\text { set }\end{array}$ & $\begin{array}{c}\text { Antecedent } \\
\text { set }\end{array}$ & $\begin{array}{c}\text { Intersec } \\
\text { tion set }\end{array}$ & $\begin{array}{c}\text { Iteratio } \\
\mathbf{n} / \\
\text { Levels }\end{array}$ \\
\hline 1. & $3,5,7$ & $1,2,3,4,5,6,7,8,9$ & $3,5,7$ & \\
\hline 2. & $2,3,5,6,7$ & $\begin{array}{c}1,2,3,4,6,7,8 \\
, 9\end{array}$ & $\begin{array}{c}2,3,6, \\
7\end{array}$ & \\
\hline 3. & $\begin{array}{c}1,2,3,5,6 \\
7\end{array}$ & $1,2,3,4,6,8,9$ & $1,2,3,6$ & \\
\hline 4. & $1,2,3,4,5,6,7$ & $1,3,4,8,9$ & $1,3,4$ & \\
\hline 5. & $\begin{array}{c}1,2,3,4,5,6 \\
, 7,8\end{array}$ & 8,9 & 8 & \\
\hline 6. & $\begin{array}{c}1,2,3,4,5,6 \\
, 7,8,9\end{array}$ & 9 & 9 & \\
\hline
\end{tabular}

From the final reachability matrix, reachability and final antecedent set for each factor are found. The element for which the reachability and intersection sets are same are the top-level element in the ISM hierarchy. After the identification of top level element, it is separated out from the other elements and the process continues for next level of elements. Reachability set, antecedent set, intersection set along with different level for elements have been shown below in table 1 to table 4 .

Table 2 : Iteration II

\begin{tabular}{|c|c|c|c|c|}
\hline S.No. & $\begin{array}{c}\text { Reachabili } \\
\text { ty set }\end{array}$ & Antecedent set & $\begin{array}{c}\text { Intersection } \\
\text { set }\end{array}$ & $\begin{array}{c}\text { Itera } \\
\text { tion }\end{array}$ \\
\hline 2. & $\mathbf{2 , 6}$ & $1,2,4,6,8,9$ & 2,6 & \\
\cline { 1 - 4 } 3. & $1,2,6$ & $1,2,4,6,8,9$ & $1,2,6$ & \multirow{2}{*}{ II } \\
\cline { 1 - 4 } 4. & $1,2,4,6$ & $1,4,8,9$ & 1,4 & \\
\hline 5. & $1,2,4,6,8$ & 8,9 & 8 & \\
\hline 6. & $1,2,4,6,8,9$ & 9 & 9 & \\
\hline
\end{tabular}

Table 3 : Iteration III

\begin{tabular}{|c|c|c|c|c|}
\hline $\begin{array}{c}\text { Sr. } \\
\text { No. }\end{array}$ & $\begin{array}{c}\text { Reachability } \\
\text { set }\end{array}$ & $\begin{array}{c}\text { Antecedent } \\
\text { set }\end{array}$ & $\begin{array}{c}\text { Intersection } \\
\text { set }\end{array}$ & $\begin{array}{c}\text { Itera } \\
\text { tion }\end{array}$ \\
\hline 3. & 1 & $1,4,8$ & 1 & \\
\cline { 1 - 4 } & $\mathbf{1 , 4}$ & $1,4,8$ & 1,4 & \multirow{2}{*}{ III } \\
\cline { 1 - 4 } 5. & $1,4,8,9$ & 8 & 8 & \\
\hline 6. & $1,4,8,9$ & 9 & 9 & \\
\hline
\end{tabular}

Table 4 : Iteration IV

\begin{tabular}{|c|c|c|c|c|}
\hline $\begin{array}{c}\text { Sr. } \\
\text { No. }\end{array}$ & $\begin{array}{c}\text { Reachability } \\
\text { set }\end{array}$ & $\begin{array}{c}\text { Antecedent } \\
\text { set }\end{array}$ & $\begin{array}{c}\text { Intersection } \\
\text { set }\end{array}$ & $\begin{array}{c}\text { Itera } \\
\text { tion }\end{array}$ \\
\hline 5. & $\mathbf{8 , 9}$ & 8 & 8 & IV \\
\hline 6. & $\mathbf{9}$ & 9 & 9 & \\
\hline
\end{tabular}

Table 5 : Iteration $\mathrm{V}$

\begin{tabular}{|c|c|c|c|c|}
\hline $\begin{array}{c}\text { Sr. } \\
\text { No. }\end{array}$ & $\begin{array}{c}\text { Reachability } \\
\text { set }\end{array}$ & $\begin{array}{c}\text { Antecedent } \\
\text { set }\end{array}$ & $\begin{array}{c}\text { Intersection } \\
\text { set }\end{array}$ & $\begin{array}{c}\text { Itera } \\
\text { tion }\end{array}$ \\
\hline 6 & 9 & 9 & 9 & V \\
\hline
\end{tabular}

\subsection{Classification of factors}

The critical success factors described earlier are classified in to four clusters viz. autonomous factor, dependent factors, linkage factors and independent factors (mentioned in Table XIII below). As it can be seen that CLC is an autonomous criteria. Criteria DTC, DOC, LTR, EC, MO , MS are drivers . Criteria such as REL, LTQP , IOIVE, LALC , ABB , LTP are dependent criteria. Criteria TE and BRS are linkage criteria. Fig. 4 below shows the driving power and dominance diagram

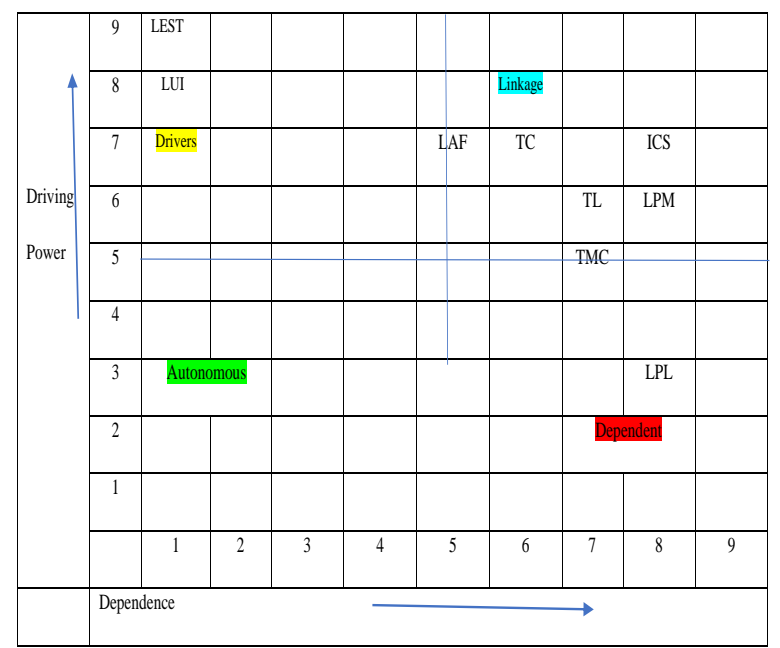

Fig . 4: Driving power and dependence diagram

\subsection{ISM model}

An ISM model is developed ( as shown in fig. 5 below ) after arranging the elements as per their interaction or dependence relationships.

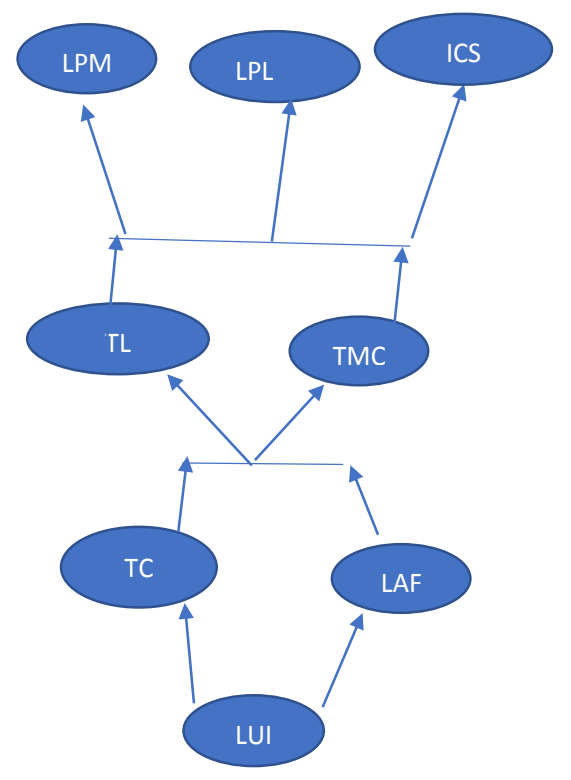

Fig 5 : ISM Model 


\section{RESEARCH IMPLICATIONS}

Present section focuses on the research implications of the fields of home science and home economics .

- Home science and ICT : ICT in the education context refers not only to the utilization of hardware devices and software applications for imparting education but also involves development and management of course content, application of web based content repositories, creation of interactive forums through the internet and satellite communication etc. home science and home economics if teach through the ICT based techniques will not only arose interest in the learners but also motivates them to bring something new and add to the existing discipline through advanced research. This also opens options for the young generations to take the discipline further into teaching and research.

- Home science pedagogies : The discipline of home science can result in highly successful pedagogies if the concerned teachers demonstrate the outstanding use of their knowledge base and understanding about home science basics. This gets further enhanced by the passion of the teachers to deliver quality material as well as research work to the learners which increases the aspirations of the learners from the field .

- Measures to be taken by government : Ministry of education should consider conducting a comprehensive review of home science education and it should be reviewed further to make it more relevant to the development goals of the country.

\section{Acknowledgement}

Author Remica Aggarwal deeply acknowledges her parents, grandparents, near and dear ones for the upbringing and love she received and pays her sincere regards for keeping trust in her. This piece of research work is a tribute to them and also to her teachers who have taught her the basics of home science and home economics.

\section{Appendix}

Educational and Vocational scope of home science

The following table 6 detailed the educational and vocational scope of home science.

Table 6 : Educational and Vocational scope of Home Science

\begin{tabular}{|c|c|c|c|}
\hline $\begin{array}{c}\text { Vocational } \\
\text { area }\end{array}$ & $\begin{array}{c}\text { Job } \\
\text { opportuniti } \\
\text { es after } \\
\text { senior } \\
\text { secondary }\end{array}$ & $\begin{array}{l}\text { Opportunitie } \\
\text { s of further } \\
\text { education }\end{array}$ & $\begin{array}{l}\text { Opportuniti } \\
\text { es after } \\
\text { advanced } \\
\text { course }\end{array}$ \\
\hline $\begin{array}{c}\text { Food and } \\
\text { nutrition }\end{array}$ & $\begin{array}{c}\text { Food } \\
\text { laboratory } \\
\text { food } \\
\text { product } \\
\text { tester, } \\
\text { kitchen } \\
\text { food } \\
\text { assembler, } \\
\text { quality } \\
\text { control } \\
\text { technicians, } \\
\text { baker }\end{array}$ & $\begin{array}{c}\text { Diploma in } \\
\text { hotel } \\
\text { management, } \\
\text { BSc (Home } \\
\text { Science), } \\
\text { Diploma from } \\
\text { Polytechnics / } \\
\text { Vocational } \\
\text { institutions }\end{array}$ & $\begin{array}{c}\text { Food } \\
\text { technician, } \\
\text { dietary } \\
\text { assistant, } \\
\text { food } \\
\text { technologist } \\
\text {, nutritionist } \\
\text {, caterer, } \\
\text { food service } \\
\text { manager }\end{array}$ \\
\hline
\end{tabular}

\begin{tabular}{|c|c|c|c|}
\hline & helper & & \\
\hline $\begin{array}{c}\text { House } \\
\text { keeping }\end{array}$ & $\begin{array}{c}\text { Guest } \\
\text { service } \\
\text { clerk, } \\
\text { house- } \\
\text { keeping } \\
\text { maid, } \\
\text { establishme } \\
\text { nt guide, } \\
\text { lodging } \\
\text { facilities } \\
\text { attendant }\end{array}$ & $\begin{array}{c}\text { Diploma in } \\
\text { hotel } \\
\text { management } \\
\text { and catering, }\end{array}$ & $\begin{array}{c}\text { Guest house } \\
\text { manager, } \\
\text { house- } \\
\text { keeping } \\
\text { manager, } \\
\text { hospitality } \\
\text { supervisor } \\
\text { hotel } \\
\text { manager }\end{array}$ \\
\hline $\begin{array}{c}\text { Interior } \\
\text { designing } \\
\text { and } \\
\text { maintenanc } \\
\text { e }\end{array}$ & $\begin{array}{l}\text { Showroom } \\
\text { assistant, } \\
\text { furnishings } \\
\text { sales } \\
\text { associate }\end{array}$ & $\begin{array}{c}\text { Diploma in } \\
\text { hotel } \\
\text { management } \\
\text { and catering, }\end{array}$ & $\begin{array}{c}\text { Window } \\
\text { display } \\
\text { designer , } \\
\text { interior } \\
\text { designer } \\
\text { assistant, } \\
\text { photo stylist } \\
\text {, furnishings } \\
\text { buyer , } \\
\text { house - } \\
\text { keeping } \\
\text { instructor }\end{array}$ \\
\hline $\begin{array}{l}\text { Consumer } \\
\text { services }\end{array}$ & $\begin{array}{c}\text { Product } \\
\text { demonstrato } \\
\mathrm{r}, \text { sales } \\
\text { representativ } \\
\mathrm{e}, \text { staff of } \\
\text { consumer } \\
\text { forum }\end{array}$ & $\begin{array}{c}\text { BSc (Home } \\
\text { Science), } \\
\text { Diploma in } \\
\text { Communicati } \\
\text { on and } \\
\text { Journalism, } \\
\text { Diploma in } \\
\text { Public } \\
\text { Relations }\end{array}$ & $\begin{array}{c}\text { Food } \\
\text { consumer / } \\
\text { products } \\
\text { tester }, \\
\text { product } \\
\text { representativ } \\
\text { e, public } \\
\text { relation } \\
\text { representativ } \\
\text { e }\end{array}$ \\
\hline $\begin{array}{c}\text { Family and } \\
\text { human } \\
\text { services }\end{array}$ & $\begin{array}{c}\text { Adult day- } \\
\text { care worker } \\
\text {, elderly } \\
\text { care worker } \\
\text {, personal } \\
\text { home care } \\
\text { aide }\end{array}$ & $\begin{array}{c}\text { BSc in } \\
\text { Home science } \\
\text {, Diploma of } \\
\text { special } \\
\text { education / } \\
\text { child } \\
\text { development } \\
\text { counsellors }\end{array}$ & \\
\hline $\begin{array}{c}\text { Child } \\
\text { development } \\
\text { and } \\
\text { education }\end{array}$ & $\begin{array}{l}\text { Family } \\
\text { child-care } \\
\text { provider } \\
\text { recreation } \\
\text { aide }\end{array}$ & $\begin{array}{l}\text { Diploma of } \\
\text { special } \\
\text { educators }\end{array}$ & $\begin{array}{l}\text { Child day- } \\
\text { care } \\
\text { supervisor } \\
\text { pre-school } \\
\text { teacher }\end{array}$ \\
\hline $\begin{array}{c}\text { Fashion } \\
\text { designing, } \\
\text { manufacturi } \\
\text { ng and } \\
\text { merchandisi } \\
\text { ng }\end{array}$ & $\begin{array}{c}\text { Fabrics / } \\
\text { accessories } \\
\text { estimator , } \\
\text { customer } \\
\text { assistant , } \\
\text { employee in } \\
\text { garment } \\
\text { manufacturi } \\
\text { ng firm }\end{array}$ & $\begin{array}{c}\text { BSc home } \\
\text { science, } \\
\text { fashion } \\
\text { designing } \\
\text { from Institute } \\
\text { of fashion } \\
\text { technology, } \\
\text { polytechnics / } \\
\text { design } \\
\text { schools }\end{array}$ & $\begin{array}{c}\text { Computer } \\
\text { imaging } \\
\text { consultant } \\
\text { merchandise } \\
\text { displayer } \\
\text { fashion } \\
\text { buyer }\end{array}$ \\
\hline
\end{tabular}


[ Adapted from National Open School Home Science lecture notes; Government of Kerala , Department of Education , SCERT,Kerala,2015 ]

\section{REFERENCES}

[1] Gluckman, P. 2011. Looking Ahead: Science Education for the Twenty-First Century (PDF 609KB). Wellington: Office of The Prime Minister's Science Advisory Committee. Inspired by Science (PDF 580KB), a 2010 paper commissioned by the Royal Society and the prime minister's chief science advisor.

[2] Fraenkel RJ and Wallen E.N. 1993. How to design and evaluate research in education (4th edition ). Illinois F.E. Peacock publishers Inc.

[3] Creswell, J.W. Plano Clark, V.L., Gutmann, M.L. and Hanson, W.E. 2003. Advanced mixed methods research designs . In Abbas Tashakkori and Charles Teddlie (Eds.). Handbook of mixed methods in social and behavioural research. Thousands oak , CA: Sage . 209240 .

[4] Mc Lean R, Laugo , J. 2005. Vocationalization of secondary education revisited. New York. Springer Publication Ltd.

[5] Chang, H., Singh, T., Mo, F. 2007. Supply and demand analysis of industrial teacher education faculty. Journal of Industrial Teacher Education 40: 60-73.
[6] Lau K., Roeser D. 2002. An Investigation of TeachingLearning Practices and Teacher-Student Readiness. Internet Journal of e-Language Learning Teaching 2: 1625.

[7] Palmer, S.G. 2001. Distance learning of technical and vocational education in Sub-Sahara Africa: Challenges and Opportunities. Journal of Home Economics 1: 1

[8] Ndiga B. 2004. Challenge of Enrolment in Technical Subjects in Secondary Schools (Case of Home science in Limuru Division Kiambu District Kenya)Educational Administration and Planning University of Nairobi.

[9] Lauglo J 2005. Vocationalised secondary education revisited Springer Netherlands, 3-49.

[10] Maina, AR.., Kitainge K. 2018. Improving Home Economics Education: A Review of Factors Militating Inclusion of Home Economics Studies in Kenyan Secondary Schools. Arts Social Sci J 9: 338. 9(2). DOI: $10.4172 / 2151-6200.1000338$.

[11] Warfield, J.N. 1974. Developing interconnection matrices in structural modeling. IEEE Transactions on Systems, Man, and Cybernetics, (1), 81-87.

[12] Standard XII HOME SCIENCE TEACHER TEXT, Teacher Text Development Team. Government of Kerala, State Council of Educational Research and Training (SCERT),Kerala, 2015 